\title{
MEDIA ADDICTIONS IN A SCHOOL ENVIRONMENT AND POSSIBILITIES OF PREVENTION
}

\author{
Katarína Cimprichová Gežová
}

\begin{abstract}
We are living in times where the media have become the main source of information, education and instruction for personal, family and social behaviour for many people. Different forms of media are competing for readers, listeners and viewers. They have growing influence on people's consciousness, feelings, opinions, values, attitudes, actions and they contribute to versatile personality development. They are also source of information and entertainment. The system of mass media has a specific position in society. It contributes to the versatile personality development as a source of information, entertainment and it also acts as a tool of unification and coordination of educational influences in the whole society. The media includes not only negative aspects, but also many positive aspects that cannot be questioned. At the same time we have to be aware of the fact that children and young people belong to a "weaker" target group, which is more predisposed to addictions, because they are not able to distinguish what is right and what is wrong for them and what can result in negative or even fatal consequences. Media addictions in school environment have and unfortunately will have a rising tendency since the technology progresses much faster than in the past. Therefore it is important to pay attention to the prevention of media addictions at schools. Although the school cannot substitute a functioning family environment and upbringing, it can help to a large extent to prevent these addictions.
\end{abstract}

\section{Keywords}

media addictions, children, young people, parents, school, prevention

\section{Introduction}

The level of science and technology development in our society is very high. New media, new communication technologies and media services are arising and have great power to influence the society in which we are losing our own opinions and adopt those foisted by media. These modern technologies are spreading not only to public life but also to 
the life of individuals. They are source of information which helps us keep contact with reality and they influence our behaviour and actions. Children and young people are very perceptive and therefore the most suggestible group. The media are for them the primary way in the process of socialisation from a very early age. They affect the attitude and opinion formation and the perception of reality. Children and young people believe that everything they hear and see is reality and adopt all the behaviour and action patterns. Nowadays, using and mastering the computer, the Internet and other modern conveniences is considered second literacy. Without this literacy one cannot get by in any field; problem-free or even professional handling of all means of communication is necessary. Today, the Internet is available to almost everybody and brings not only many positives, but also some negative aspects in the form of addictions or cyberbullying. These addictions have a rising tendency and the age bracket of the media addicted is younger every year. Even the children commencing the primary education show indications of media addictions.

\section{The causes of media addictions by children and young people}

Substance and non-substance addictions are described as addictive behaviour belonging to socio-pathological phenomena. The society is developing along with the changing spectrum of socio-pathological phenomena. The changes take place not only in the field of drug addictions, but also in the field of non-substance addictions, for example the rapid expansion of new so-called communication addictions (Hupková, 2009, p. 82).

The emergence and development of addictions is determined by the interaction of many factors that affect the personality and disorders of individuals. These are cultural, environmental and interpersonal factors. The addiction arises as a consequence of unfulfilled internal inducements, needs and goals. These include the endogenous and exogenous factors which are direct and indirect causes of the emergence and development of addiction (Fedorová \& Hardy, 2014, p. 111).

1. Biological factors - genetic (congenital) predisposition, central nervous system damage, chronic diseases, sensory defects, impulse control disorder.

2. Psychological factors - personality disorder, negative destructive emotions and affective disorders, trauma, post-traumatic stress disorder, feeling like nothing makes sense, low self-control, low emotional control, low selfconfidence, ADHD, impulsiveness, instability, signs of psychopathy, low selfrespect and others.

3. Social factors - family system dysfunction, incomplete family system, undesirable parental attitude such as rejection, disturbed relations, disorder of family function, socio-pathological phenomena in family, ineffective use of leisure time, divorce of the parents, communication block in the family system, inability to handle stressful situations, insufficient social support and others (Fedorová \& Hardy, 2014, p. 111-113). 
The authors Escandón and Gálvez (2012, p. 123) present external causes that can be the triggers to an addiction. These are:

- increase in productivity, consumerism and advertising - people look for new and immediate pleasure and then succumb easily to this phenomenon, especially when speaking about novelties,

- socio-economic triggers - include family breakdown, fast pace of life, depression, anxiety of individuals,

- "bombardment" of sensations - e. g. the situation when a shopaholic needs to possess something new which is a current trend or novelty,

- information overload - people are scared of excessive number of bad news presented by the mass media, the press or the Internet,

- materialism - when people take unconscious and ineffective actions that get them into tense situations in which they resort to substance or non-substance addictions.

The addiction itself is in many cases a consequence of another problem. Children and young people often replace another deficit with an addiction, be it lack of attention from their parents or missing friendships, boredom and others. Other causes that can give the rise to an addiction include (Gregussová \& Drobný, 2013):

- boredom,

- failure in real life, problems at school,

- parents' lack of interest, lack of spending the time together,

- conflicts in family,

- missing friendships,

- psychological problems,

- need for venting frustration and accumulated anger (bullying).

Almost everybody in our surroundings has Internet access and it means not only positives but also many risks that come with it. We use computers and Internet on a daily basis. The Internet, phoning and texting can be potential sources of pleasant feelings. If people are not aware of the risks, this relationship can develop into a mental disorder closely related to addiction to addictive substances (Emmerová, 2011, p. 50). Pathological relationship to Internet and computers has analogy to six features defining any addiction:

1. feature: strong desire or compulsion, so-called craving,

2. feature: problems with self-control,

3. feature: habit-breaking state,

4. feature: increase in tolerance,

5. feature: progressive neglect of hobbies and interests,

6. feature: continuation in spite of harmful consequences (Hupková, 2009, p. 82).

Holdoš (2013, p. 9) defines the Internet addiction as an individual inability to control the use of the Internet which leads to stress and functional disturbance of daily activities. It is excessive Internet use which brings to the life of individuals psychological, social and other complications. 
Causes of emergence of Internet addiction:

- feeling of excitement - people look for something exciting on the Internet. They search for websites which are interesting for them a which bring them the feeling of excitement and euphoria,

- reduction of tension - calming down by chatting and playing Internet games,

- new feeling of identity - the communication on the social networks enables the anonymous users to adopt various social identities on themselves,

- looking for company - virtual communities provide space for escape from reality, they create ways to fulfil unsatisfied social or psychological needs,

- biological aspects - people use the Internet to change their mood, when they are bored, feel isolated or full of anxiety,

- psychological problems - depression, phobia, impulse control disorder and attention deficit disorder,

- family situation - unfavourable family conditions which can develop into an inclination to addictive behaviour (Sejčová, 2011, p. 95-96).

There are different triggers that can lead to addictive behaviour on the Internet. Benkovič (2007, p. 250-253) claims that these are mostly long-lasting conflict situations in families and at schools because consequently people withdraw within themselves, to their internal idealized world and they look for the way out in the alternative virtual world - on the Internet. Situations that lead to addictive behaviour on the Internet can have great impact on cyberbullying, which is one of the most frequent negative phenomena on the Internet. It is not something new, it is just occurring in another space. With the expansion of modern technologies the considerable part of bullying moved to a virtual setting. It is easier for the aggressors to hurt somebody they do not have to be in direct contact with, do not have to look into their eyes, they perceive the emotions and harms of the victims to a lesser extent, they are less aware of the seriousness of their actions and the responsibility thereof. This kind of bullying can seem to them as a kind of harmless entertainment. At the same time, the anonymity of aggressors protects them from discovery. For the victims, virtual bullying is even more serious - they cannot escape from it, even not to the safety of their homes. If they use a mobile phone or the Internet, the aggressors can reach them any time and in any place (Gregussová \& Drobný, 2013). The mobile phone is a phenomenon of the present days. Mobile phone communication has influenced a major part of the middle and young generation to such extent that its sudden absence leads to stress, loss of comfort and, in many cases, even to addiction. We often use a mobile phone not only for phoning but also for spending our free time in that we excessively use text messages, surf on the Internet or play different games. The mobile phone has become a phenomenon of the present. The mobile phone addiction belongs to the contemporary phenomena. People suffering from mobile phone addiction are not able to move away from their mobile phones for more than few minutes. With the massive arrival of smartphones that are connected online to Internet applications, this addiction is growing even more, because it is supported by the Internet addiction or virtual communication (Fischer \& Škoda, 2014, p. 133). 
Pokorný, Telcová, \& Tomko (2002, p. 209) presents four examples of risks that come with the use of mobile phones:

- people lose the ability to rely on themselves in common and difficult situations, they do not practise basic social skills,

- disturbance of social contacts, disturbance of communication and relationships,

- parents who do not have enough time for their children provide them with mobile phones. They think they are still bringing their children up, at least partially, or even that they are "in",

- mobile phone enables escape from difficult situations which they would be otherwise taught to handle.

Excessive use of mobile phones belongs to the non-substance addictions and is as destructive as a substance addiction. In the present fast-moving times full of technologies, we can hardly find a person who would not welcome this modern form of communication and quick contact with people. The mobile phone addiction develops gradually. At first, it is about "an inevitable need", and then it is an alternative to personal contact or quick information transfer. At the beginning, people may use the phone just to get or check certain information, but later they have compulsive need to use the mobile phone on every occasion. Permanent and unreasonable holding of mobile phone in our hands can warn us about possible addiction. Internet access, E-mail, camera or mp3 player are selfevident in a mobile phone. There are some preferred marks and types of mobile phones that children and young people try to possess. Phoning by mobile phones has become a standard and sort of ritual which gives us the feeling of importance and prestige (Juríková, 2015). The non-substance addictions include, apart from the Internet and mobile phone, also other phenomena, such as playing computer games, gaming machines, excessive TV watching and many others that can seriously threaten the development of children and young people and can have destructive and even fatal impact on them.

\section{Impact of media addictions on children and young people}

The means of massive information and propaganda have not only positive but also negative impacts on children and young people. Specialized discussions about the negative impact are lead more and more often, since the most analysed is the violence in television, on the Internet and in different magazines and the impact on aggressive undisciplined behaviour of children and adolescents thereof.

Undesirable effects of media on children are according to McQuail (2009, p. 500-501) mainly as follows:

- rising social isolation,

- less time and attention for homework,

- rising passivity,

- less time for playing and movement,

- less time for reading (because of television), 
- undermining of parental activities,

- premature sexual knowledge and experiences,

- unhealthy food and obesity,

- extreme personal grooming leading to anorexia and bulimia,

- inclination to depression.

Many researches point to a very negative impact on children, especially negative impact on attention, value orientation and speech:

- attention disturbance of children - successful children's TV programmes are based on plot twists, so that children will sit in front of TV and will constantly be surprised. Time intervals between these twists are very short, only about 35 seconds. If children watch this kind of programmes a lot, they lose the ability to concentrate on events without such a twist, for example: lessons at school, long-term leisure activity, etc.;

- value of authentic personal experiences is disturbed - children suffering from television addiction lose sensitivity to events they can experience by themselves, events which they can experience through television are more appealing for them, it means for them to experience something through someone else, through their heroes. The development of personal identity is disturbed and they lose sense of their own lives. We must keep in mind that the programme offer for children also gives rise to aggressive behaviour;

- speech reduction to primitive heard dialogues - the ability to speak in advanced and respectful way, to listen to the opinions of other people, to argue and to accept the arguments of other people is suppressed;

- children enforce the programmes according to the current trend, what is popular among the classmates, friends. It comes to imitating and identification, where educational corrections are needed but hardly enforceable. So aggression, impudence and similar phenomena spread to the mentality of children;

- specific problem is "caricatured childhood" - the notions of caricatured childhood are implanted in children as a sign of the fact that adults understand them. When children accept this role and "successfully play" it, it comes necessarily to conflicts between them and adults. Children lose the basic orientation in themselves and the seriousness of demands which are placed on them (Helus, 2004, p. 65-66).

Children and young people create profiles in a community web. These are based on such information as age, sex, residence, hobbies, photographs, videos. These can be seen and shared by other users. Children and young people use social networking even more than phones and recently even more than communication and face-to-face dialogues. This kind of communication is the easiest way to maintain contact and friendships and serve as substitution for social relations. There is a risk of loss of privacy but also of addiction emergence, which can be caused by the Internet. The biggest risks include the loss of privacy by misuse of data, identifying with the virtual reality, access to inappropriate contents and social risks connected with threatening, harassment and aggression. 
The biggest danger that threatens healthy psychological and moral development of children and young people are the websites with pornographic contents in form of texts, photographs and films (Kunák, 2007). Micháleková (2003) claims that children live in a fictional environment, lose the need and ability to express their feelings and fears. They lose the ability of orientation in a real world and physical skilfulness. They can come into contact with information that can endanger their further development without their parents even knowing it. They consider violence the most effective and the only way of solving conflicts. They start to lose creative and free thinking and think in a schematic way. They have the tendency to express themselves in curt and short commands. They are disoriented in the area of ethical norms and values (especially in connection with combat games and games full of violence). Kilčík (Katedra základov a vyučovania informatiky, n.d.) points to the negative impacts of media addictions, since they can give rise to aggression and simulated violence in which they can participate. That way their tendency to hurt somebody would be even higher because of these reasons:

- children are highly susceptible to reiterate after individuals who they can identify with. Most of the violent games put the player in the role of a shooter or other kind of executor of violent actions and so create the connection between the aggressor from the game and the player controlling the game,

- in contrast to television that is passive, the games require active participation. This can support the incorrect impression that the executed actions are acceptable since they were included in the game,

- it is known that learning is easier by repeating. The elements in the game are repeating and so teaching to be violent,

- people and especially children learn easier and more voluntary if they are rewarded for their effort.

Spálová (2013, p. 62-63) describes several theories connected with the negative consequences of mass media. They are as follows:

1. Theory of imitation - there is a possibility that on the basis of displayed socially undesirable behaviour the individual can learn how to perform violence or criminal acts. Television programmes provide a specific form of aggression, a pattern worth of imitation that the viewer adopts. Watching of media violence often leads to imitating aggressive behaviour patterns in real life.

2. Theory of habituation - according to this theory, when people are repeatedly exposed to visual violence, they become insensitive, their emotional sides are numbed and after a certain time, the violence is considered normal. Then they become more tolerant of real violent behaviour that they witness.

It is desired to deal with violence, aggression, brutality and inappropriate social behaviour that is provided by mass media and that is fertile ground for arising of other inappropriate phenomena - impulses that form the personality of children and young people and often even adult population, in a negative way. 


\section{Possibilities of preventing media addictions in school environment}

Internet, computer and phone addiction is a serious social and medical problem which concerns almost all age groups. Like by other addictions, prevention is very important. Addiction prevention is understood as an activity leading to prevention of undesired influences, its goal is health protection and upbringing to a healthy way of life (Rol'ková, 2015 , p. 63). Family should lay the foundations of immunization of children against sociopathological phenomena because family is the initial educational and socialization factor and parents represent the first educational and human models for their children. Children transfer what they learn in their families to their own lives and also to other social groups in which they live. Therefore a social pedagogue influences in a preventive way the children via a positive model, right value orientation, education to right use of leisure time and love to their families and this in an intentional and nonintentional way. On the other hand, a family is a lay educational institution and the parents often make mistakes in upbringing and preventive influence on children (Hroncová, Emmerová, \& Hronec, 2014, p. 257). Sharp increase in socio-pathological phenomena by children and young people, increase in consumer lifestyle, negative impact of mass media, negative spending of leisure time and increase of social problems in society require the profession of social pedagogue. Specific task of a social pedagogue in the past was to act as a coordinator of drug addiction prevention and prevention of other socio-pathological phenomena (Emmerová, 2008, p. 147). According to the Law No. 245/2008 Journal of Laws about upbringing and education as amended and Law No. 317/2009 Journal of Laws about pedagogical and specialised stuff as amended, a social pedagogue is classified into a system of education consultancy and prevention as a specialised staff in schools, as well as school, special, educational and consultancy facilities. Law about pedagogical and specialised staff No. $317 / 2009$ characterises in $\S 24$ a social pedagogue as follows: "A social pedagogue carries out professional activities within prevention, intervention and providing advice especially for children and pupils threatened by socio-pathological phenomena, from socially disadvantaged backgrounds, drug addicts or in other way disadvantaged children and pupils, for their legal representatives and pedagogical staff in schools and school facilities. A social pedagogue fulfils the tasks of social education, support of prosocial and ethical behaviour, socio-pedagogical diagnostics of environment and relations, socio-pedagogical consultancy, prevention of socio-pathological phenomena and behaviour re-education. He carries out the expertise and enlightenment". A social pedagogue belongs to very specific professions, because within his focus is the work with children and young people, he participates in the formation of their personalities, he helps to develop their dispositions and preconditions. He also works in the area of primary prevention with the orientation on all children and young people but also in the area of secondary prevention with the orientation on children and young people from socially disadvantaged backgrounds. Considering this, a social pedagogue must have certain personal qualities that predestine him for the work with children and young people (Snopková, 2013, p. 21). Emmerová (2004, p. 201) defines the personal qualities of a social pedagogue as follows: 
- he himself is a model of healthy lifestyle and he is convinced about the correctness and effectiveness of prevention,

- he is a personality that can communicate, cooperate and coordinate the activities with pupils, colleagues, school leaders and partners of other organisations,

- he has preconditions for dealing with relationships but also extreme life situations, especially from the point of view of health protection,

- he has preconditions for personal growth and further self-education etc.

Bakošová (2005, p. 180-184) was the first in Slovakia to divide the competences of social pedagogues. Specific competences of a social pedagogue include socio-educational competence, competence of re-education, counselling competence, competence of prevention and competence of management. With the competence of prevention the author points out the use of a social pedagogue in prevention of socio-pathological phenomena and she describes particular tasks of a social pedagogue at schools according to the orientation of the target group and that in relation to pupils, teachers and parents. Other tasks in prevention of media addiction include creation and realisation of preventive programmes, such as conflict resolution programmes, bullying prevention programmes, truancy prevention programmes, healthy lifestyle programmes, programmes of creation of social competences etc. A social pedagogue is adequately trained and competent to carry out the education about social competences of pupils, especially of pupils from socially disadvantaged backgrounds and of those who come to school with low level of social competences. So his task is to create programmes, trainings, games and other activities that can lead to education and strengthening of mentioned skills. Part of the education of mentioned competences is to offer educational, leisure, preventive and training activities for teachers, parents, to at least partially align the goal of school and family education by formation of social competences, (Bakošová et al., 2011, p. 117) that play a significant role in the realisation of preventive programmes focused on media addictions. They are as follows:

1. Preventive programme Med - the programme is designed for pupils from the fourth year in primary schools; the goal is a media education with the orientation on chosen risk factors that follow from the daily media influence.

2. Teambuilding - the programme is oriented on improving relations in a class, functioning of a class group, improving the communication among pupils, improving the group cohesion and cooperation. This programme is designed primarily for newly created groups.

3. Body and Image and Self-Perception - it is a preventive programme dedicated to discussions to the topic of self-assessment, perception of one's own body and impact of the media on self-image (Centrum pedagogickopsychologického poradenstva a prevencie Bratislava IV., n.d.).

4. A Way to an Emotional Maturity - it is about strengthening one's own personality capacities and it is designed for pupils aged from 12 to 15 years.

5. How to Become Yourself - this preventive programme is designed as a 
supplementary teaching text for secondary school pupils, in which it offers useful information about the forms of socio-pathological phenomena and solutions of emergency situations (Frívaldská, 2015).

Like other scientific disciplines, social pedagogy distinguishes three basic levels of prevention of socio-pathological phenomena. It is the primary, secondary and tertiary prevention.

Primary prevention is the basis for preventive effect on children and young people. Nowadays, the emphasis is put mainly on primary prevention that should prevent the emergence of deviant behaviour of children and young people, therefore it should be realised on a professional level. It is the professionalism that increases its effectiveness and decreases the need of secondary prevention (Hroncová, Emmerová, \& Hronec, 2014, p. 256).

Secondary prevention is directed and focused on endangered groups of children and young people; it does not concern all pupils. Its goal is to prevent the emergence of disorders of social and psychological development, to detect them in their early stage and to provide the measures necessary for high-risk or endangered pupils (Hroncová, Emmerová, \& Hronec, 2014, p. 257).

Tertiary prevention represents activities focused on preventing the relapse of undesired behaviour. It is a part of a long-term social rehabilitation and is carried out on a professional level via the staff of social rehabilitation facilities (Emmerová, 2011, p. 88).

In connection with prevention we can be point towards media education that, according to the document Conception of Media Education in the Slovak Republic in the Context of Lifelong Learning of 2009, is defined as a systematic and goal-directed process of gaining media competences and increasing the level of media literacy with the goal to support responsible media use and to develop critical attitudes towards media contents with the emphasis on moral principles and humanism (Emmerová, 2011, p. 54). Media education comes to the foreground as a result of computerisation of schools and dangers of the media. Its main goal is to teach all age brackets a responsible attitude to media and media contents, to teach them to use new communication technologies and to protect them from illegal and unsuitable contents. Media education has the potential to decrease the harmful effects of media and emphasize the positive effects. Media education appears to be a possible prevention of undesired online influences; it represents the way of how to teach a valuable way of media life and to protect from highrisk online behaviour (Hollá, 2013, p. 20).

Media education as the prevention of online high-risk behaviour:

- eliminates negative impacts of media that contribute to the rise of unsuitable behaviour,

- eliminates the uncritical acceptation of media contents,

- eliminates the prejudices and gender stereotypes coming from the media,

- eliminates the deformed view of values that threaten and harm children's development, 
- strengthens responsible behaviour in cyberspace and beyond it,

- strengthens critical acceptation of media contents and messages,

- strengthens positive use of media through its work with it,

- strengthens reasonable use of leisure time (Hollá, 2013, p. 20).

Young people build a target group to which we must pay particular and permanent attention to in connection with primary prevention of so-called substance (drug) and non-substance addictions. Especially young people aged from 13 to 20 years are a highrisk group and the probability of contact or experimentation with substance and nonsubstance addictions, including the modern communication technologies, is very high. It must be emphasized that the contemporary phenomenon of so-called communication addictions can endanger people of all age groups. All these facts are a strong call for preventive intervention (Hupková, 2009, p. 83). The lack of preventive and educational influence of families on children should be compensated by schools. Social pedagogy has always put emphasis on the compensation of the shortcomings in families to prevent deviant development of children and young people. Compensative function in relation to families in prevention of socio-pathological phenomena must be carried out, especially by schools and educational consultancy and prevention facilities (Hroncová, Emmerová, \& Hronec, 2014, p. 256). Addictive behaviour of substance and non-substance nature belongs according to many authors (e.g. S. Fischer, J. Škoda, B. Kraus, J. Hroncová, P. Ondrejkovič and others) to the most serious socio-pathological phenomena. On account of this, it is necessary that the social pedagogue is familiar with, can recognize and be helpful in not only primary prevention but also successful intervention and solution of a given problem (Hupková \& Liberčanová, 2012, p. 58).

\section{Conclusion}

Nowadays, the media participate more and more intensively in personality development since early childhood. Childhood without television, Internet, Facebook and other media is all in the past now. The impact on children and young people thereof is on the one hand positive, since they get information in every area which supports their personality development. On the other hand, it comes more and more often to disturbance of personality which manifests itself by aggressive behaviour, increased stress, decreased self-control, insufficient real relationships, which can lead to loneliness, depression, cyberbullying and other negative features of media influence. The best prevention of media addictions is effective and early prevention since eliminating consequences requires more effort and resources by solving existing problems, while many consequences are already irreversible. It is necessary that our society reacts in time to this problem via effective prevention at all levels - primary, secondary and tertiary. 


\section{References}

Bakošová, Z. (2005). Sociálna pedagogika ako životná pomoc [Social Education as Life Support]. Bratislava: Comenius University, Faculty of Arts.

Bakošová, Z. et al. (2011). Teórie sociálnej pedagogiky. Edukačné, sociálne a komunikačné aspekty [Theory of Social Pedagogy. Educational, Social and Communicational Aspects]. Bratislava: Glasstrading.

Benkovič, J. (2007). Novodobé nelátkové závislosti [New Age Disorders of Non Substance Dependences]. Psychiatrie pro praxi [Psychiatry for Practice], 8(6), 250-253.

Centrum pedagogicko-psychologického poradenstva a prevencie Bratislava IV. [Centre for Educational Psychological Counselling and Prevention Bratislava IV.] (n.d.). Retrieved from http://www.psychologickeporadenstvo.sk

Emmerová, I. (2004). Koordinátor prevencie drogových závislostí a dálších sociálnopatologických javov [Coordinator for the Prevention of Drug Addiction and Other SocioPathological Phenomena]. In Sociálna patológia [Social Pathology]. Banská Bystrica: Matej Bel University.

Emmerová, I. (2008). Spoločenská potreba profesionálneho uplatnenia sociálneho pedagóga v školskom prostredí [Societal Needs of Professional Application of Social Educators in School Environment]. In Socialia 2007. Prevencia sociálnopatologických javov u detí, mládeže a dospelých [Socialia 2007. Prevention of Socio-Pathological Phenomena in Children, Adolescents and Adults] (pp. 146-150). Banská Bystrica: Matej Bel University.

Emmerová, I. (2011). Aktuálne otázky prevencie problémového správania u žiakov $v$ školskom prostredí [Current Questions on Prevention of Problem Behaviour of Students in School Environment]. Banská Bystrica: Faculty of Education, Matej Bel University.

Escandón, R., \& Gálvez, C. (2012). Slobodní od závislostí [Free from Addictions]. Vrútky: Advent-Orion.

Fedorová, M., \& Hardy, M. (2014). Závislost' a rodina [Addiction and Family]. In F. Kubík, \& J. Kutarňa (Eds.), Rodina - výzva pre sociálnu politiku a pomáhajúce profesie. Zborník prednášok zo IV. medzinárodnej vedecko-odbornej konferencie v Žiline 21. marca 2014 [The Family - A Challenge for Social Policy and Helping Professions. Proceedings of Lectures of the IV. International Scientific and Professional Conference in Žilina, 21 March 2014] (pp. 111-119). Bratislava: St. Elisabeth University of Health Care and Social Work.

Fischer, S., \& Škoda, J. (2014). Sociální patologie. Závažné sociálně patologické jevy, 
přičiny, prevence, možnosti řešení [Social Pathology. Serious Social Pathologies, Causes, Prevention, Possible Solutions]. Prague: Grada.

Frívaldská, I. (2015). Svetlo z tmy v protidrogovej prevencii učitelá: osvedčená pedagogická skúsenost' edukačnej praxe [Light from Darkness in Preventing DrugAddiction as a Teacher: Best Practice from Educational Experience]. Retrieved January 25, 2018, from https://mpc-edu.sk/sites/default/files/projekty/vystup/15_ops_frivaldska_ ivana_-_svetlo_z_tmy_v_protidrogovej_prevencii_ucitela.pdf

Gregussová, M., \& Drobný, M. (2013). Deti v sieti: ako chránit' seba a naše deti na internete [Children in Nets: How to Protect Ourselves and Our Children on the Internet]. Retrieved January 15, 2018, from https://www.zodpovedne.sk/index.php/sk/component/ jdownloads/finish/1-knihy-a-prirucky/9-kniha-deti-v-sieti-2013-14?ltemid=0

Helus, Z. (2004). Dítě v osobnostním pojetí. Obrat $k$ dítěti jako výzva a úkol pro učitele i rodiče [Child in Personality Concept. Turnover to Child as a Challenge and Task for Teachers and Parents]. Prague: Portál.

Holdoš, J. (2013). Závislost' od internetu u mladých ludí [Internet Addiction in Young People]. In Výchova a vzdelávanie ako nástroj (de)formovania hodnotového systému spoločnosti. Zborník z konferencie [Education and Training as a Tool of (De)Formation of the Value System of Society. Proceedings of the Conference] (pp. 6-15). Ružomberok: VERBUM.

Hollá, K. (2013). Mediálna výchova ako prevencia online rizikového správania [Media Education as a Prevention of Online Dangerous Behavior]. Pedagogické rozhlady [Pedagogical Views], 22(4-5), 19-21.

Hroncová, J., Emmerová, I., \& Hronec, M. (2014). Sociálna patológia pre sociálnych pedagógov [Social Pathology for Social Pedagogues]. Banská Bystrica: Belianum.

Hupková, I. (2009). Komunikačné závislosti [Communication addictions]. Bedeker zdravia [Bedeker of Health], 5(6), 82-83.

Hupková, I., \& Liberčanová, K. (2012). Drogové závislosti a ich prevencia [Drug Addictions and Their Prevention]. Trnava: Trnava University in Trnava, Faculty of Education.

Juríková, T. (2015). Mobilmánia: Chorobná závislost' od mobilného telefónu [Mobilmania: Disease Addiction to Mobile Phone]. Retrieved from https://www.slovenskypacient.sk/ mobilmania-chorobna-zavislost-od-mobilneho-telefonu/

Katedra základov a vyučovania informatiky [Department of Informatics Education]. (n.d.). Retrieved from http://www.edi.fmph.uniba.sk 
Kunák, S. (2007). Vybrané možnosti primárnej prevencie negatívnych vplyvov na deti a mládež [Selected Possibilities of Primary Prevention of Negative Influence on Children and Youth]. Bratislava: Iris.

McQuail, D. (2009). Úvod do teorie masové komunikace [Introduction to the Theory of Mass Communication]. Prague: Portál.

Micháleková, L. (2003). Hráčska závislost' [Gambling Addiction]. In Poruchy správania a učenia [Behavioral Disorders and Learning Disorders] (pp. 1-28). Bratislava: Raabe.

Pokorný, V., Telcová, V., \& Tomko, A. (2002). Patologické závislosti [Pathological Addictions]. Brno: Ústav psychologického poradenství a diagnostiky [Department of Psychological Counselling and Diagnostics].

Rol'ková, H. (2015). Závislosti spojené s využivaním moderných komunikačných technológií [Addictions Associated with the Use of Modern Communication Technology]. In M. Madro, \& B. Holíková (Eds.), Virtuálna generácia. Sme dnes iní ako kedysi? Zborník príspevkov z odbornej konferencie Virtuálna generácia [Virtual Generation. Are We Different Today from Who We Used to Be? Proceedings of Contributions from the Scientific Conference Virtual Generation] (pp. 55-65). Bratislava: Pan-European University, Faculty of Psychology.

Sejčová, Ĺ. (2011). Mladí v sieti závislostí [The Youth in the Web of Addictions]. Bratislava: Album.

Snopková, I. (2013). Osobnost' sociálneho pedagóga a jeho kompetencie [The Personality and Competences of a Social Educator]. In J. Hroncová, I. Emmerová, \& K. Kropáčová et al., Preventívna sociálno-výchovná činnost'v škole. (Metodická príručka pre sociálnych pedagógov a koordinátorov prevencie) [Preventive Socio-Educational Activities in School. (Methodological Handbook for Social Pedagogues and Prevention Coordinators)]. Banská Bystrica: Matej Bel University.

Spálová, L. (2013). Transdisciplinárne prístupy v mediálnom výskume [Transdisciplinary Approach in Media Research]. Nitra: Constantine the Philosopher University in Nitra.

Zákon č. 245/2008 Z. z., o výchove a vzdelávaní (školský zákon) a o zmene a doplnení niektorých zákonov [Law No. 245/2008 Journal of Laws about upbringing and education (Education Act) as amended]. (2008).

Zákon č. 317/2009 Z. z., o pedagogických zamestnancoch a odborných zamestnancoch a o zmene a doplnení niektorých zákonov [Law No. 317/2009 Journal of Laws about pedagogical and specialised stuff as amended]. (2009). 


\section{Author}

PhDr. Katarína Cimprichová Gežová, PhD.

Faculty of Education, Matej Bel University

Department of Pedagogy

Ružová 13, 97411 Banská Bystrica, Slovak Republic

katarina.gezova@umb.sk 